19 Revue d'histoire du XIXe siècle

Société d'histoire de la révolution de 1848 et des

révolutions du XIXe siècle

$12 \mid 1996$

L'incendie

\title{
Incendies et incendiaires en Eure-et-Loir au XIXe siècle
}

Jean-Claude Farcy

\section{OpenEdition \\ Journals}

Electronic version

URL: http://journals.openedition.org/rh19/86

DOI: $10.4000 /$ rh 19.86

ISSN: $1777-5329$

\section{Publisher}

La Société de 1848

\section{Printed version}

Date of publication: 1 June 1996

ISSN: 1265-1354

Electronic reference

Jean-Claude Farcy, «Incendies et incendiaires en Eure-et-Loir au XIXe siècle », Revue d'histoire du XIXe siècle [Online], 12 | 1996, Online since 04 September 2008, connection on 20 April 2019. URL : http:// journals.openedition.org/rh19/86 ; DOI : 10.4000/rh19.86

This text was automatically generated on 20 April 2019

Tous droits réservés 


\section{Incendies et incendiaires en Eure- et-Loir au XIXe siècle}

Jean-Claude Farcy

\section{ABSTRACTS}

No abstract available by now

Pas de résumé disponible actuellement

INDEX

Mots-clés: Incendie, Histoire sociale 